Public transit fare structure and social vulnerability in Montreal, Canada

\author{
David Verbich \\ School of Urban Planning \\ Faculty of Engineering \\ McGill University \\ Room 401, Macdonald-Harrington Bldg. \\ 815 , rue Sherbrooke Ouest \\ Montreal QC Canada \\ H3A 0C2 \\ david.verbich@mail.mcgill.ca
}
Ahmed El-Geneidy (corresponding author)
School of Urban Planning
Faculty of Engineering
McGill University
Room 401, Macdonald-Harrington Bldg.
815 , rue Sherbrooke Ouest
Montreal QC Canada
H3A 0C2

Tel: 514-398-8742

Fax: 514-398-8376

ahmed.elgeneidy@mcgill.ca

\title{
December 2016
}

For citation please use: Verbich, D. \& El-Geneidy, A. (2017). Are the transit fares fair? Public transit fare structures and social vulnerability in Montreal, Canada. Transportation Research Part A: Policy and Practice, 96,43-53. 


\begin{abstract}
Research on social equity pertaining to transportation typically addresses how residents in a region have access to desirable destinations. Nonetheless, little is known about how public transit fare structures relate to social equity concerns. Some transit agencies charge more for fewer rides - weekly fares often cost more per ride than unlimited monthly fares, though monthly fares cost more upfront. For some social groups, in particular low-income earners, purchasing monthly passes may place a burden on their budget, and influence them to buy weekly passes instead. In this study, we analyze transit fare purchases of total monthly, weekly, and three or more weekly passes during the month of September 2014 in Montreal, Canada. We discovered that fare vendors in neighborhoods with low median household income and/or with a high proportion of unemployed residents are predicted to sell more weekly fares than vendors in neighborhoods with high household income and low rates of unemployment. Monthly fare purchases were not dependent on income or unemployed residents. Moreover, using smartcard data to track individual fare cards, we found that recurring purchases of three or more weekly passes depend on income and unemployment, so neighborhoods with socially vulnerable individuals are predicted to have more riders purchasing multiple weekly fares than socially secure neighborhoods. Our findings indicate that individuals residing in marginalized neighborhoods are likely to spend more money on transit fares over the course of a month compared to those residing in wealthy neighborhoods. These findings raise concerns regarding the financial burden that the existing fare structure in the city of Montreal imposes, especially on low-income groups. The methodology and findings from this study provide insight for transport planners, particularly those concerned with providing an equitable public transit system.
\end{abstract}

KEYWORDS: Transit fares, Monthly fares, Weekly fares, Low-income, Equity 


\section{INTRODUCTION}

A public transit network capable of moving many residents to diverse locations is an integral characteristic of any city. A large focus of public transit research deals with scheduling and operations or travel behavior and mode share, but fewer studies have investigated fare structures and purchasing. Moreover, from a social equity perspective, a growing body of literature has asked whether transit benefits and projects are distributed equitably in a region (Delbosc \& Currie, 2011; Foth, Manaugh, \& El-Geneidy, 2013; Manaugh, Badami, \& El-Geneidy, 2015; Martens, 2012, 2017), but fewer studies have addressed the equity impacts of fare structures. Indeed, transit fares may form an important barrier for the working poor (Stolper \& Rankin, 2016). One recent example of research on fare structures was a study in New York City, where researchers discovered that entries at subway stations in low-income census tracts were predominately from seven-day fare cards, while entries at stations in higher income census tracts were largely from monthly fare cards (Hickey, Lu, \& Reddy, 2010). In New York City — as in many other cities - purchasing multiple weekly fares as a substitute for a monthly fare costs more in the long run since buying in bulk is cheaper. However, low-income earners may be unable to spend a large amount at one time for a monthly fare, opting instead to buy weekly fares that are cheaper in the short-term but costlier in the long-term (Schuerman, 2015; Stolper \& Rankin, 2016).

In this paper, we investigate how purchases of different transit fare types may relate to social vulnerability, particularly income and unemployment, with implications for social equity. We studied purchases of transit fares using OPUS card transaction records, the transit fare smartcard of the transit agency of the Island of Montreal, Canada, the Société de transport de Montréal (STM) (STM, 2015). To shed light on the spatial and socioeconomic factors that underlie different types of fare purchases, we model the number of total monthly fares purchased, total weekly fares purchased, and the number of riders who purchased three or more weekly fares during September 2014. We hypothesize that some low-income earners and unemployed residents may be unable to purchase monthly passes because of the high upfront cost, and buy weekly passes as a substitute; while a weekly pass is less expensive upfront, buying three or more weekly passes over the course of the month is costlier (per ride). Based on our hypothesis, we expect to find concentrations of weekly fare transactions predominately in low-income neighborhoods, and we also predict that income will be a significant explanatory 
variable of three or more weekly fare sales that we hereafter refer to as recurring, repeated, or multiple weekly fare sales.

The paper begins with a review of the relevant literature on transport equity and transit fares. Next, we provide background on the Montreal context and transit fare structure of the STM, Montreal's main transit provider. Third, we describe our dataset, methods, and modeling approach. Fourth, we explain our models and findings. Lastly, we discuss our findings and potential policy relevance.

\section{LITERATURE REVIEW}

An emerging body of literature has brought social equity concerns to the forefront of many disciplines, including land use and transportation planning (Geurs, Boon, \& Van Wee, 2009; Martens, 2012). Nevertheless, in many instances, what equity entails is murky including equity in transportation planning (Manaugh et al., 2015) and the definition of equity itself (B. D. Taylor \& Norton, 2009). Generally, equity in reference to planning, as espoused by Krumholz and Forester (1990), means allocating more resources to those who have the least. This idea would propose ensuring that socially vulnerable populations, who are typically bound to transit (APTA, 2007), have a larger share of transportation-related benefits, such as accessibility to jobs by transit (Foth et al., 2013) or access to transit itself (Delbosc \& Currie, 2011; Wasfi, Ross, \& ElGeneidy, 2013; Welch, 2013), than individuals with more transport options, like a private vehicle. With regard to transit fares, an equitable scheme consistent with Krumholz and Forester (1990) thesis would be one where low-income individuals pay less, while individuals who can afford to pay more will pay a greater fare (Aggarwala, 2012).

Many different fare schemes are used by transit agencies with varying impacts on social equity. In North American cities, many transit agencies charge flat fares for city bus and subway services (Cervero, 1981), regardless of distance traveled or mode. Since low-income residents tend to live in central city neighborhoods well-served by transit (Glaeser, Kahn, \& Rappaport, 2008), these residents likely travel shorter distances and thus are poorly served by flat fares. On the other hand, commuter rail tends to be zonal in fare structure and is mostly used by affluent white-collar workers (B. Taylor \& Morris, 2015). These schemes also apply to Montreal, where one flat fare is used for city buses and metros, but commuter rail fares are zonal. Recent work using spatial modeling to examine a switch from flat to distance-based fares found that this 
switch is advantageous for minority and low-income riders in Wasatch Front, Utah (Farber, Bartholomew, Li, Páez, \& Nurul Habib, 2014). In addition to considering fares based on distance or time of day, different fares types, such as monthly unlimited or weekly unlimited passes are also used by many agencies. The price-per-ride of a monthly pass is usually less expensive than weekly or daily single fares.

With varying fare schemes, demand for transit can be managed. For example, longer trips in Beijing are most affected by fare increases (Wang, Li, \& Chen, 2015), while in New York City, estimated ridership loss is less for increases in unlimited monthly fares compared to weekly fare increases (Hickey, 2005), implying that sensitivity of ridership depends on fare structure and type. By evaluating several scenarios of Alameda-Contra Costa Transit, California, Nuworsoo, Golub, and Deakin (2009) found that vulnerable riders, including low-income riders, youth, and minorities would be penalized more by scenarios that would increase flat fares per ride due to more transfers and more trips compared to affluent riders who could afford to purchase a monthly pass. In contrast to agencies with flat fares or costlier fares for fewer rides, in Washington, D.C., distance and peak trips determine transit fares, and per ride, weekly fares cost the same as monthly fares (WMATA, 2015). Washington's approach to charging lower fares during off-peak hours could address some equity concerns (B. D. Taylor \& Norton, 2009). To specifically address vulnerable populations who depend on transit, transit agencies in San Francisco, Seattle, and Calgary, for example, have programs for subsidized transit passes for low-income riders (SFMTA, n.d.; C. Transit, 2015; K. C. Transit, 2015).

Nevertheless, few studies have considered the factors underlying transit fare purchases. By estimating travel demand in Athens, Greece, researchers uncovered that the fare type can influence ridership, and this varies by mode as well as fare price (Gkritza, Karlaftis, \& Mannering, 2011). While that study used some sociodemographic indicators, namely income and immigrant status, to determine their association with fare purchases, detailed demographics were lacking. This is likely due to the inability to link riders and demographics directly. Given the scarce research on income and transit fare purchasing with implications for social equity, a closer examination of how income can influence transit fare purchases is warranted. 


\section{DATA AND METHODOLOGY}

\section{Montreal background and context}

Montreal is the second largest metropolitan region in Canada, at roughly 4 million inhabitants, and is located in the south of the province of Quebec. The City of Montreal, along with on-island municipalities, is located on Montreal Island in the Saint Lawrence River, and is served by the STM, the local transit agency operating the metro and buses on the Island. The regional transit authority runs suburban trains that feed central intermodal stations in downtown Montreal.

Launched in 2008-2009, the OPUS smartcard fare system is used by transit agencies throughout the Greater Montreal region (STM, 2015). OPUS card users purchase a card (\$6.00 CAD) and then load fares onto the card at metro and train stations, as well as at authorized vendors throughout the region. In our study, we focused on transactions from vendors and stations located only on the Island of Montreal and its associated islands (including Île-Bizard and Île-des-Soeurs) (Fig. 1), the STM's major service area.

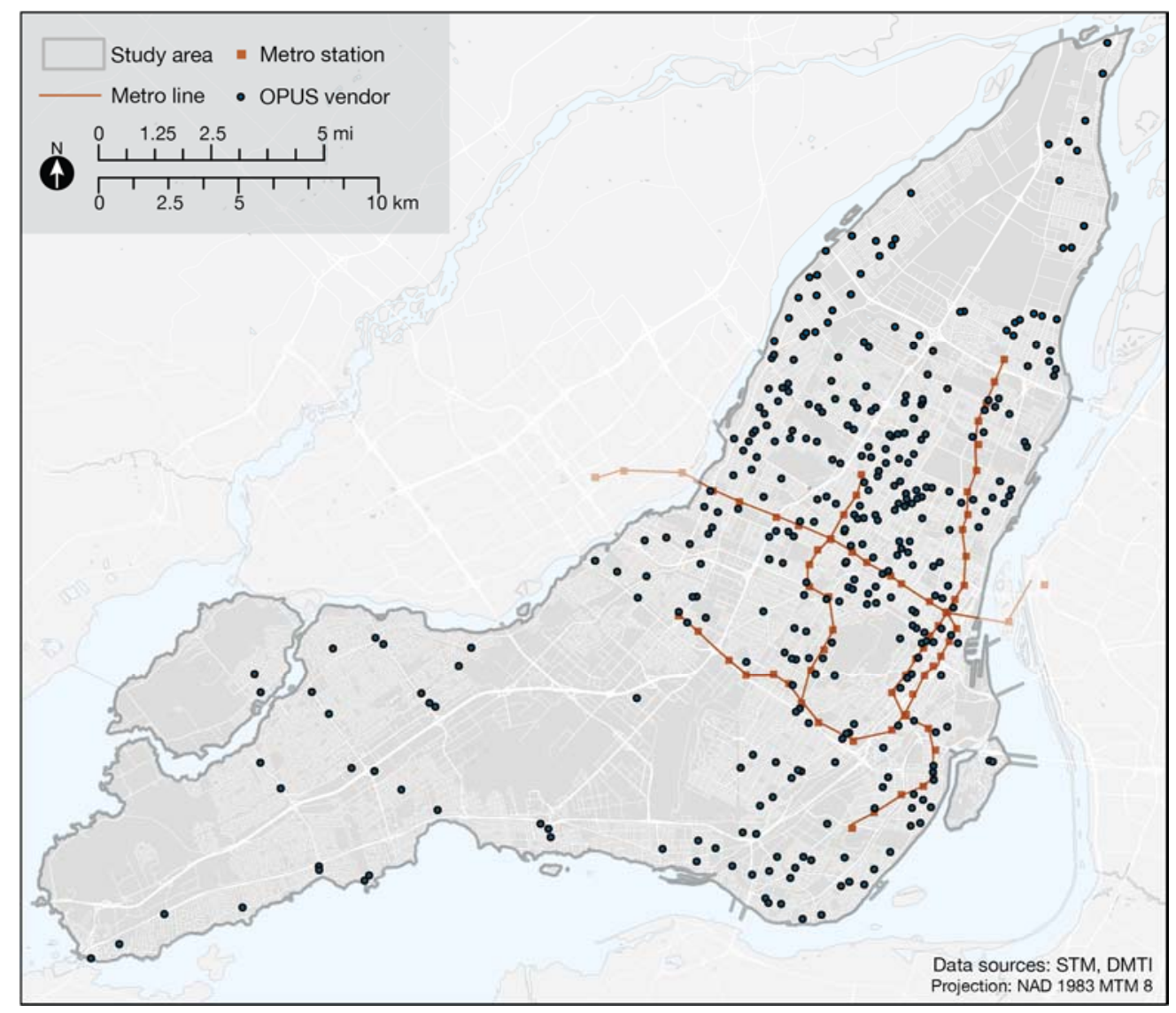

Figure 1. Context map showing fare vendors (metro stations and local vendors). 
In 2014 , a single fare cost $\$ 3.00$, while a two-way trip fare cost $\$ 5.50$. Weekly fares (valid from Monday 5 a.m. to Sunday 11:59 p.m.) cost \$24.50, and monthly fares (valid from the first day to the last day of the month) cost $\$ 79.50$, so buying weekly passes (four) for an entire month is costlier overall than purchasing a monthly pass. Moreover, when buying three weekly passes in a month, spending $\$ 6.00$ more, or the equivalent cost of two single trips, would have enabled unlimited monthly access; buying a monthly pass instead of three weekly passes is more sensible. While reduced-cost senior and student fare cards are personalized with photo IDs, regular OPUS cards are not personalized nor registered to a single user.

While we initially wished to study a larger time frame of purchases (six months), the time requirements to extract transaction data are significant, and thus we limited our data request to a single month. To our knowledge, no special events occurred in September 2014 that would have significantly affected fare sales, and we chose September to limit the number of potential tourist sales during summer months or weekly sales because of residents' holidays during the summer.

\section{Data preparation}

A total of 1,010,720 fare purchases were completed within the month of September 2014. These transactions originated from 602,609 unique OPUS cards and took place both at transit stations (70 locations/Metro or transit stations) and points of sales such as corner stores and pharmacies (363 vendors). Note that these transactions include all cards that made purchases, ranging from single fares, to monthly fares, to suburban train fares, as well as multiple purchases. Moreover, these transactions included both regular and reduced fare purchases, which include purchases made by students under 18 years old, students between 18-25 years old, and seniors over 65 years old. For this study, only regular fares are examined because reduced fares cannot be stratified into different groups (students vs. seniors) due to price equivalence. For the five calendar weeks in September 2014, 63,262 regular weekly passes were sold at transit stations and 34,707 were sold at local vendors. In terms of monthly passes (both for September and October pass, since monthly passes are available on the $20^{\text {th }}$ day of the preceding month), 145,970 were sold at transit stations while 57,762 were sold at local vendors.

For data preparation (Fig. 2), fare purchases originating from metro stations off the Island of Montreal were removed because off-island residents need to buy fares for their regions (and were not recorded in our dataset) as well as fares to access the STM system (present in our dataset). Also records from the main passenger airport were removed because of the non- 
residential nature of the surrounding area and potential skewing due to tourist purchases. Any records that contained more than one purchase of the same fare type (e.g., two of the same week or two of the same month) were also removed as errors. In all, transactions taking place at a total of 407 different points of sale (interchangeably referred to as 'locations' including 64 transit stations and 343 local vendors) are analyzed in this study. The final analyses included 61,959 weekly fares from transit stations (2\% removed) and 32,892 weekly fares from vendors (5\% removed). For monthly fare transactions, 144,688 fares were analyzed from transit stations $(<1 \%$ removed) and 53,394 monthly fares from vendors (7\% removed). To analyze recurring purchases of weekly fares (three or more weekly fare purchases during the month), individual OPUS IDs were extracted and only IDs that made repeated purchases at a single point of sale (i.e., excluding IDs that bought multiple weekly passes at different locations) were examined. We also excluded IDs that purchased repeated weekly fares as well as monthly fares. This subset contained 5,395 unique purchasers of three or more weekly fares at a unique location in the month of September 2014.

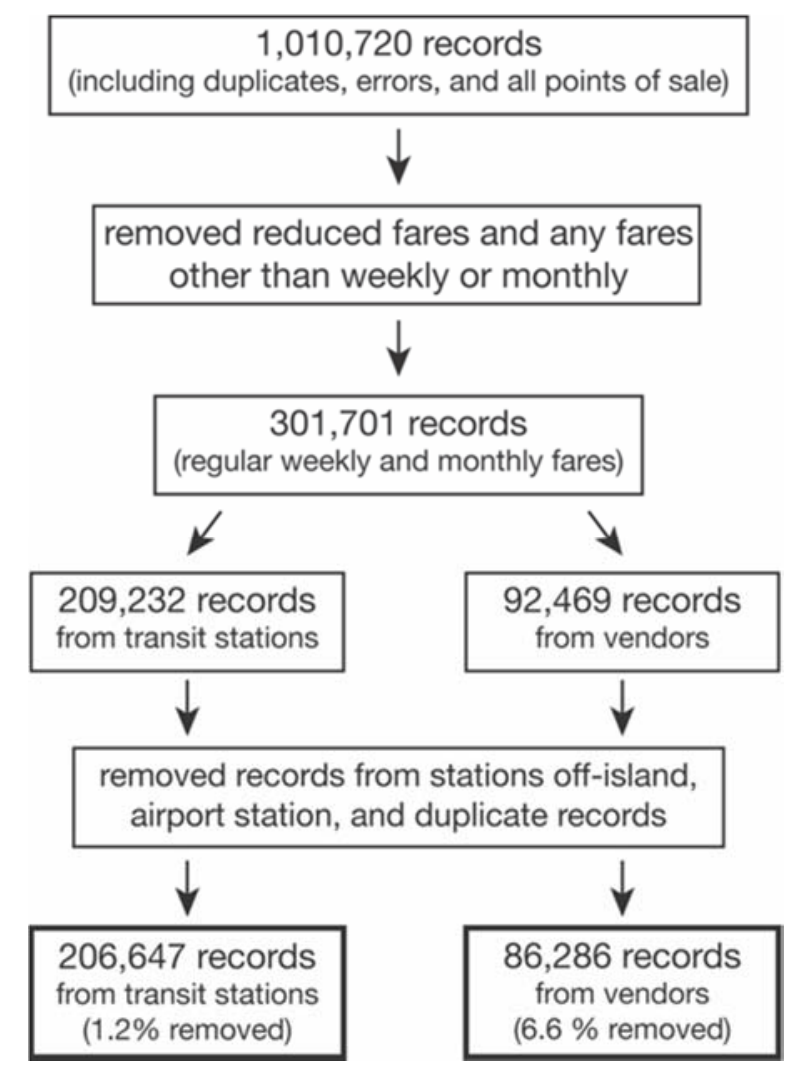

Figure 2. Data preparation. 
The dependent variables (Table 1) are the total number of monthly fares purchased at a location, the total number of weekly fares purchased at a location, and the number of purchasers of three or more weekly fares from a unique location. When testing for normality with ShapiroWilks, Shapiro-Francia and skewness tests, as well as visually analyzing a frequency plot of dependent variables, we determined that the dependent variables were not normally distributed. Moreover, five vendors had no weekly sales and 52 vendors had no three or more weekly sales. To deal with non-normality and vendors with zero sales (data records with dependent variables equal to 0), we used negative binomial regression modeling (see Statistical modeling below).

\section{Demographic and spatial variables}

To link neighborhood characteristics to each vendor, we generated a 500-meter network buffer around the centroid of every vendor's postal code using the Montreal street network. These buffers were intersected with census tracts to assign median household income within the buffer around each vendor, and the contribution of each census tract was weighted based on area. The same procedure was used for metro stations, but a 1-km network buffer was used instead, assuming the greater draw of metro stations and larger than assumed walking distances to transit in Montreal (El-Geneidy, Grimsrud, Wasfi, Tétreault, \& Surprenant-Legault, 2014). Moreover, the percent of unemployed residents was also calculated with the same method unemployed residents may be prone to purchase weekly passes due to the uncertainty of travel or due inability to afford a monthly pass. A similar procedure was used to calculate population within the buffer. Finally, categorical variables related to the built environment (metro stations, hub stations, bus stops, commuter stations, and other vendors) were determined as falling within the network buffer or not, and distance to the downtown center point (CBD) was calculated using network analyst in a GIS.

To generate the maps in Figure 3, individual points of sale were assigned to the census tract that contributed the greatest area proportion. Then, median income, total monthly fares, total weekly fares, and total three or more purchasers were normalized by calculating z-scores for each point of sale. Finally, the $z$-scores for each variable (by point of sale) were summed by census tract and displayed as deciles on a map. Hollow census tracts do not contain points of sale. Note that these maps were used for display purposes, as the unit of analysis is a point of sale and not a census tract (or neighborhood). 


\section{Statistical modeling}

Given the non-normal and skewed nature of the dependent variables, transit fare purchases, as well as the fact that the dependent variables are count data, we used negative binomial regression modeling. This method has the advantage of dealing appropriately with skewed and count data, and we also tested whether this technique was more appropriate than Poisson modeling if the variance is larger than the mean (likelihood ratio test). In addition, for models with dependent variables equal to 0 (five vendors had no weekly sales and 52 vendors had no three or more weekly sales), we first tested whether zero-inflated negative binomial regression was appropriate (Vuong test of zero-inflated vs. standard negative binomial regression). The Vuong test proved that zero-inflated negative binomial regression was unnecessary for both total weekly fare $\left(\operatorname{Pr}_{r}>\mathrm{z}\right.$ $=0.50)$ and recurrent weekly fare $\left(\mathrm{P}_{\mathrm{r}}>\mathrm{z}=0.08\right)$ purchase models. Therefore, all models were specified as standard negative binomial models.

Moreover, to account for the variability in transit fare sales between points of sale located within the same census tract, we used multilevel regression modeling when appropriate (tested with a likelihood ratio test). Multilevel modeling acknowledges the hierarchical nature of data, such as individuals nested within different levels like neighborhoods. Specifically, by accounting for hierarchical relationships, multilevel modeling meets the assumption of the independence of observations that ordinary least square regressions may violate. Multilevel modeling permits allocating the variance to lower (point of sale) and higher (neighborhood) levels. In other words, if the variance in the data is due to variance between the neighborhoods, the multilevel technique reports it in the model, while the variance from within the neighborhood is controlled for and does not affect the other reported variances or the coefficients. The use of this technique is becoming more widespread in social sciences and has been used recently in several publications in the transport field (Djurhuus, Hansen, Aadahl, \& Glümer, 2014; Familar, Greaves, \& Ellison, 2011; Wasfi et al., 2013). Each point of sale was assigned to a census tract based on the census tract that made the largest area contribution from the GIS-generated network buffer. In Montreal, census tracts are valid proxies for neighborhoods (Ross, Tremblay, \& Graham, 2004). In this study, we used census tracts as a level to visualize and understand the effect of the individual location and neighborhood characteristics on transit fare sales. 
Note that specifying the models as either linear regressions (ln-transformed), multilevel linear (ln-transformed) regressions, or multilevel Poisson regressions, by and large yielded similar results in terms of magnitude and sign of the variables of interest, income and unemployment, demonstrating the stability of the models and overall soundness of the conclusions drawn from the results.

\section{RESULTS}

Table 1 lists and describes the variables used in this paper, as well as the summary statistics of the variables. Every point of sale sold an average of 233 weekly passes and 486 monthly passes, suggesting that over the course of a month, more riders buy monthly passes. In terms of recurring weekly pass sales, an average of 13 riders purchased three or more weekly passes at every vendor in September 2014. Table 1 demonstrates that for both types of fares, standard deviations are high indicating a large variation in sales among points of sale.

Table 1. Description of Variables and Summary Statistics.

\begin{tabular}{|c|c|c|c|}
\hline Variable name & Description & Mean & Std. Dev. \\
\hline Income & $\begin{array}{l}\text { Median household income (Canadian dollars) within the } \\
\text { buffer (divided by } \$ 10,000 \text { ) }\end{array}$ & 4.50 & 1.44 \\
\hline Unemployed & $\begin{array}{l}\text { Percent of residents who are unemployed within the } \\
\text { buffer }\end{array}$ & 10.08 & 2.86 \\
\hline Population & Population within the buffer (divided by 1,000 ) & 4.02 & 1.25 \\
\hline Distance to CBD & $\begin{array}{l}\text { Network distance }(\mathrm{km}) \text { from vendor or metro station to } \\
\text { downtown center point }\end{array}$ & 9.62 & 6.00 \\
\hline Distance to $\mathrm{CBD}^{\wedge} 2$ & Square-term of network distance to downtown & 128.39 & 168.62 \\
\hline Metro (dummy) & $\begin{array}{l}\text { Dummy variable equal to } 1 \text { if the point of sale is a metro } \\
\text { station }\end{array}$ & 0.15 & 0.36 \\
\hline Hub (dummy) & $\begin{array}{l}\text { Dummy variable equal to } 1 \text { if the metro station is a } \\
\text { major transfer station or the main downtown station }\end{array}$ & 0.037 & 0.19 \\
\hline Metro stations & $\begin{array}{l}\text { Number of metro stations located within the buffer } \\
\text { (excluding the metro station that is the vendor itself) }\end{array}$ & 0.34 & 0.82 \\
\hline Bus stops & Number of bus stops located within the buffer & 25.59 & 26.87 \\
\hline Commuter stations & Number of commuter stations located within the buffer & 0.057 & 0.26 \\
\hline $\begin{array}{l}\text { Other vendor } \\
\text { (dummy) }\end{array}$ & $\begin{array}{l}\text { Dummy variable equal to } 1 \text { if a vendor (non-metro) is } \\
\text { located within the buffer }\end{array}$ & 0.56 & 0.50 \\
\hline \multicolumn{4}{|l|}{$\begin{array}{l}\text { Dependent } \\
\text { variable }\end{array}$} \\
\hline Total monthly fares & $\begin{array}{l}\text { Total monthly fares (September and October) sold in the } \\
\text { month of September }\end{array}$ & 486.69 & 897.27 \\
\hline Total weekly fares & $\begin{array}{l}\text { Total weekly fares (calendar weeks } 36,37,38,39 \text { and } \\
40 \text { ) sold in the month of September }\end{array}$ & 233.05 & 386.16 \\
\hline
\end{tabular}


IDs 3 or more

Number of unique OPUS IDs purchasing 3 or more

13.26

21.21

weekly fares at unique points of sale

$N=407$ points of sale (64 Metro/transit stations and 343 vendors); 258 neighborhoods/census tracts

Figure 3 a shows that the neighborhoods with the lowest median incomes (blue hues) are located in the north, southwest and some central parts of the island. By mapping standardized values (z-scores) for monthly fare, weekly fare, and recurring weekly fare purchases, it appears that census tracts with low-incomes had the greatest purchases of all types of fares (red hues, Fig. 3b-d). These maps show that vulnerable neighborhoods are where the transit fare sales are above the mean, consistent with the notion that socially vulnerable groups use public transit the most (Giuliano, 2005; B. Taylor \& Morris, 2015).
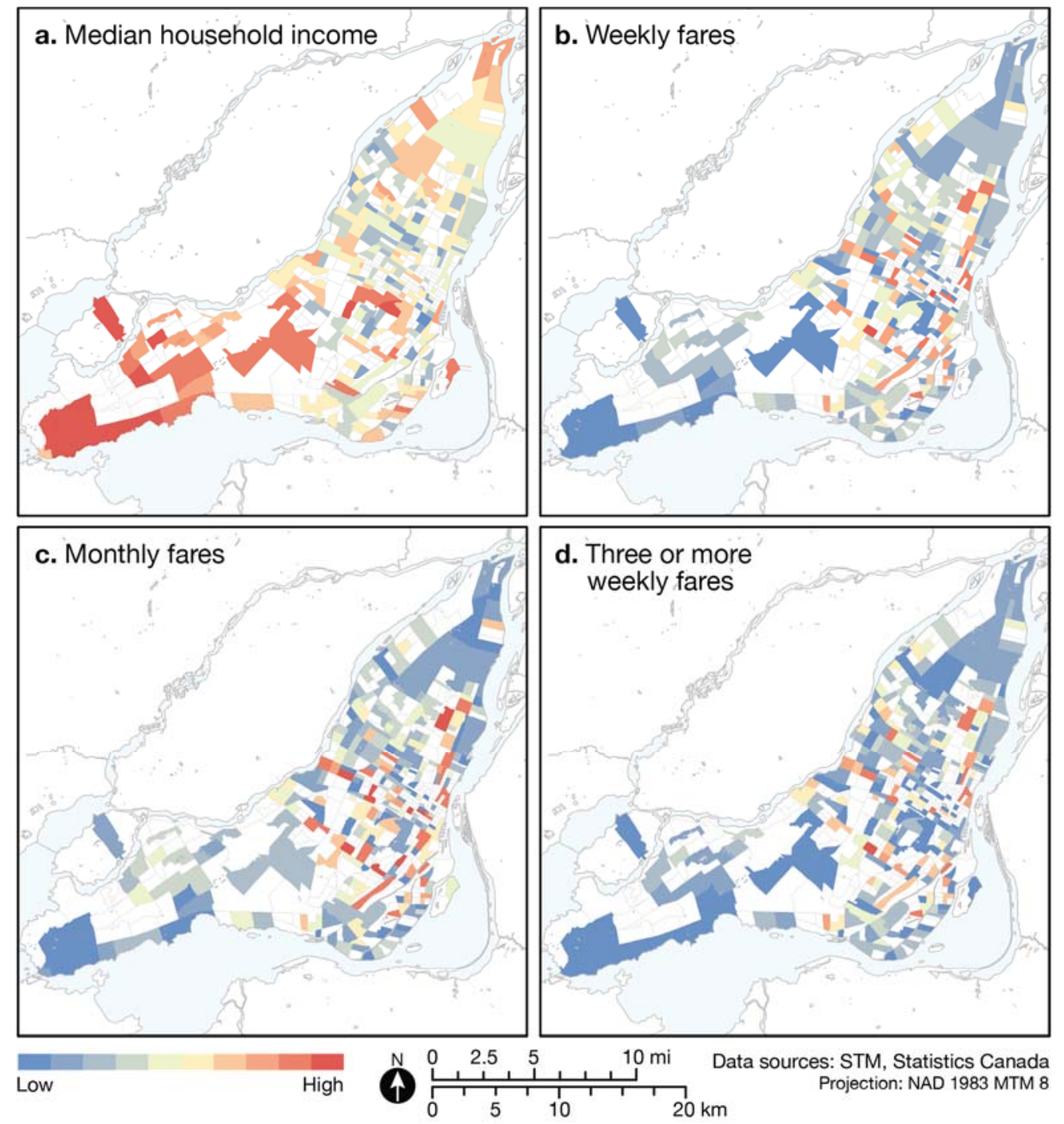

Figure 3. Income and fare purchase deciles. 


\section{Transit fare purchase models}

Using negative binomial regression modeling to account for data skewness and count data (fare purchases), we developed three different models to determine how different variables contribute to the purchasing of the different fare types. Specifically, we asked how fare purchases at points of sales depend on median income and unemployment levels of the neighborhood surrounding it while controlling for a number of spatial characteristics, such as transit stops and distance to CBD.

First, we analyzed total monthly fare sales using a multilevel negative binomial regression (likelihood test, $\mathrm{P} \geq \chi^{2}=0.01$ ). This model is based on 198,082 total monthly fare transactions from 407 points of sale. Table 2 shows the output of the model with median household income as the variable of interest.

Income is not a significant predictor variable of monthly fare purchases, suggesting that individuals with all levels of income buy monthly fares. Moreover, the percentage of unemployed residents in a neighborhood does not impact monthly fare purchases. The control variables show that for every 1,000 residents in a neighborhood, $22 \%$ more monthly fares will be purchased. If the sales location is a metro station, $205 \%$ more monthly fares are sold compared to local vendors. In addition, $1.6 \%$ more monthly fares are purchased for every bus stop within the vicinity of the sales point, while having a commuter station within proximity of the vendor will decrease monthly fare sales by $45 \%$, likely because transit riders in these more suburban areas will purchase commuter fares (not analyzed here).

TABLE 2 Model 1 - Monthly Fare Purchase Model

\begin{tabular}{|c|c|c|c|}
\hline Variable & Coefficient & $\begin{array}{l}95 \% \text { CI } \\
\text { Lower } \\
\text { bound }\end{array}$ & $\begin{array}{c}95 \% \mathrm{CI} \\
\text { Upper } \\
\text { bound } \\
\end{array}$ \\
\hline Income & 0.020 & -0.078 & 0.12 \\
\hline Unemployed & 0.038 & -0.0029 & 0.080 \\
\hline Population & 0.22 & 0.11 & 0.33 \\
\hline Distance to CBD & 0.021 & -0.047 & 0.088 \\
\hline Distance to $\mathrm{CBD}^{\wedge} 2$ & -0.0012 & -0.0035 & 0.0011 \\
\hline Metro (dummy) & 2.05 & 1.40 & 2.69 \\
\hline Hub (dummy) & 0.53 & -0.0023 & 1.08 \\
\hline Metro stations & -0.072 & -0.29 & 0.15 \\
\hline Bus stops & 0.016 & 0.0047 & 0.027 \\
\hline Commuter stations & -0.45 & -0.90 & -0.012 \\
\hline Other vendor (dummy) & -0.076 & -0.29 & 0.14 \\
\hline Constant & 3.29 & 2.49 & 4.10 \\
\hline Census tract - Variance & 0.14 & 0.053 & 0.36 \\
\hline
\end{tabular}




\begin{tabular}{rc}
\hline Number of observations & 407 points of sale \\
Number of groups & 258 census tracts/neighborhoods \\
Log-likelihood & -2603.32 \\
Prob $>\chi^{2}$ & 0.00 \\
AIC & 5234.63 \\
BIC & 5290.76 \\
Bold indicates $\mathrm{P}<0.05$ &
\end{tabular}

Next, we analyzed total weekly fare purchases based on 94,851 transactions from 407 points of sale. First, we specified a multilevel negative binomial regression model using total weekly sales as the dependent variable; running the model as a multilevel was not statistically appropriate (likelihood test, $\mathrm{P} \geq \chi^{2}=0.45$ ). Therefore, we specified the model as a standard negative binomial regression. The output of Model 2 is reported in Table 3.

Table 3. Model 2 - Weekly Fare Purchase Model.

\begin{tabular}{|c|c|c|c|}
\hline Variable & Coefficient & $\begin{array}{c}95 \% \text { CI } \\
\text { Lower } \\
\text { bound }\end{array}$ & $\begin{array}{r}5 \% \mathrm{CI} \\
\text { Upper } \\
\text { bound }\end{array}$ \\
\hline Income & -0.11 & -0.20 & -0.029 \\
\hline Unemployed & 0.076 & 0.041 & 0.11 \\
\hline Population & 0.14 & 0.042 & 0.23 \\
\hline Distance to CBD & 0.19 & 0.13 & 0.26 \\
\hline Distance to $\mathrm{CBD}^{\wedge} 2$ & -0.0060 & -0.0080 & -0.0038 \\
\hline Metro (dummy) & 1.83 & 1.23 & 2.42 \\
\hline Hub (dummy) & 0.47 & -0.055 & 0.99 \\
\hline Metro stations & -0.19 & -0.40 & 0.015 \\
\hline Bus stops & 0.020 & 0.0096 & 0.031 \\
\hline Commuter stations & 0.0019 & -0.40 & 0.40 \\
\hline Other vendor (dummy) & -0.13 & -0.32 & 0.069 \\
\hline Constant & 2.17 & 1.47 & 2.86 \\
\hline Number of observations & \multicolumn{3}{|c|}{407 points of sale } \\
\hline Log-likelihood & \multicolumn{3}{|c|}{-2339.46} \\
\hline Prob $>\chi^{2}$ & \multicolumn{3}{|l|}{0.00} \\
\hline AIC & \multicolumn{3}{|l|}{4704.92} \\
\hline $\mathrm{BIC}$ & \multicolumn{3}{|l|}{4757.03} \\
\hline Bold indicates $\mathrm{P}<0.05$ & & & \\
\hline
\end{tabular}

For every $\$ 10,000$ increase in median income of the neighborhood is predicted to decrease weekly fare purchases by $11 \%$, suggesting that in neighborhoods with low incomes, weekly fare sales are greater than in neighborhoods with high incomes. A percentage increase in unemployed residents residing in the neighborhood is expected to increase the sale of weekly 
purchases by $7.6 \%$. In addition, every 1,000 persons in a neighborhood will increase total weekly fare sales by $14 \%$. For every $1-\mathrm{km}$ farther from the CBD, there is a $19 \%$ increase in weekly fare purchases until a certain distance, where every additional kilometer reduces sales by $0.60 \%$ (distance to $C B D^{\wedge} 2$ ). This suggests that sales locations in inner-city neighborhoods will sell more weekly fares compared to farther, more suburban neighborhoods. Access to mass transit will also increase the purchasing of weekly fares - every nearby bus stop within the vicinity of a sales location will increase weekly fare purchases by $2.0 \%$. Overall, this model shows that income and unemployment are explanatory variables for weekly fare purchases.

Finally, we analyzed how recurring weekly fare purchases depend on income. Model 3 (Table 4) is based on 5,395 unique purchasers (smartcard IDs) that bought three or more weekly fares during the month. Similar to Model 1 above, Model 3 was first specified as a multilevel negative binomial regression to account for the non-normality of the dependent variables and locations with no purchasers of three or more weekly fares; multilevel specification was unnecessary (likelihood test, $\mathrm{P} \geq \chi^{2}=0.08$ ).

Table 4. Model 3 - Three or More Recurrent Weekly Fare Purchase Model

\begin{tabular}{|c|c|c|c|}
\hline Variable & Coefficient & $\begin{array}{l}\text { 95\% CI } \\
\text { Lower } \\
\text { bound }\end{array}$ & $\begin{array}{c}95 \% \\
\text { CI } \\
\text { Upper } \\
\text { bound }\end{array}$ \\
\hline Income & -0.16 & -0.26 & -0.060 \\
\hline Unemployed & 0.075 & 0.040 & 0.11 \\
\hline Population & 0.10 & 0.0038 & 0.20 \\
\hline Distance to CBD & 0.24 & 0.17 & 0.30 \\
\hline Distance to $\mathrm{CBD}^{\wedge} 2$ & -0.0068 & -0.0091 & -0.0044 \\
\hline Metro (dummy) & 1.98 & 1.38 & 2.57 \\
\hline Hub (dummy) & 0.32 & -0.17 & 0.83 \\
\hline Metro stations & -0.35 & -0.56 & -0.14 \\
\hline Bus stops & 0.018 & 0.0072 & 0.029 \\
\hline Commuter stations & -0.019 & -0.42 & 0.38 \\
\hline Other vendor (dummy) & -0.12 & -0.32 & 0.080 \\
\hline Constant & -0.45 & -1.26 & 0.36 \\
\hline Number of observations & 407 points of sale & & \\
\hline Log-likelihood & -1237.98 & & \\
\hline Prob $>\chi^{2}$ & 0.00 & & \\
\hline $\mathrm{AIC}$ & 2501.96 & & \\
\hline $\mathrm{BIC}$ & 2554.07 & & \\
\hline Bold indicates $\mathrm{P}<0.05$ & & & \\
\hline
\end{tabular}


Model 3 reveals that for every $\$ 10,000$ increase in median household income in a neighborhood, 16\% fewer recurring weekly fare purchases will be made, suggesting that in neighborhoods with low incomes, more transit riders will buy repetitive weekly fares compared to neighborhoods with high incomes. The percentage of unemployed residents will also increase recurring weekly fare purchases by $7.5 \%$, revealing that unemployed residents, likely on fixed incomes, repetitively purchase weekly fares to substitute for a monthly fare. Moreover, for every 1,000 persons in a neighborhood, 10\% more recurrent weekly purchases will take place. Every kilometer increase from the CBD increases recurrent weekly purchases by $24 \%$, until a given distance, where $0.68 \%$ fewer types of these purchases will be made. Recurring purchases will be made significantly more at metro stations, since metro station sale locations will see $198 \%$ recurring weekly fare sales compared to local vendors. Interestingly, the presence of a metro station close by will compete for recurring weekly sales at a vendor of interest, reducing these sales by $35 \%$. The presence of bus stops will also modestly increase the percentage of recurring weekly pass purchases by $1.8 \%$. Taken together, these models show that weekly fare purchases, but not monthly fare purchases, depend significantly on median household income and employment status.

While developing these statistical models, we tested other variables previously used as proxies or indicators of social vulnerability (Foth et al., 2013), including immigration status, educational achievement, and worker skill level. Using a combined social indicator, our preliminary results revealed that greater social vulnerability predicted greater fare purchases of all types, but of weekly fares to a larger degree than monthly fares (data not shown). Moreover, we tested whether the percentage of part-time workers residing in a neighborhood could explain weekly fare transactions, with the idea that part-time workers who are unsure of shift scheduling would buy weekly fares. Interestingly, this variable was not statistically significant in any of the models tested (data not shown). Finally, note that the above models were tested using different model specifications and modeling techniques - the impact of the policy-relevant variables (income and unemployment) were found to be stable and statistically significant across all models and all modeling techniques. 


\section{DISCUSSION AND CONCLUSION}

By modeling transit fare purchase records from September 2014, we discovered that in neighborhoods with lower median incomes and higher levels of unemployment, fare vendors will sell significantly more weekly fares overall, as well as have more purchasers of recurring of weekly fares than vendors in neighborhoods with higher median incomes and lower levels of unemployment. Given that weekly passes in Montreal are more expensive per trip compared to monthly passes, our findings suggest that income instability can spur the purchase of repetitive weekly fares. Moreover, the proportion of part-time workers is not a significant explanatory variable for recurrent weekly passes, implying that part-time workers are not driving the sale of recurrent weekly fares, supporting the idea that low-income individuals substitute monthly fares for multiple weekly fares (Hickey et al., 2010; Schuerman, 2015). As a consequence, financially vulnerable riders are more likely to be spending more income over the course of a month than riders who can afford to pay for the monthly pass in a single payment. Future work should address how transit agencies strive to balance fares and profits with maximizing ridership and network efficiency.

For vulnerable populations, financial affordability is usually the first hurdle to accessing public transit (Stolper \& Rankin, 2016), and access to viable transit for marginalized populations, including residents who lack private cars (Delbosc \& Currie, 2012), is necessary to reach jobs and other opportunities (Martens, 2017). As transit agencies regularly increase fares (Hickey, 2005), the burden falls hardest on marginalized groups, in particular when buying monthly fares. The steep upfront cost of a monthly pass may be unaffordable for low-skilled workers who are paid weekly or biweekly (Schuerman, 2015); they may opt instead to buy weekly passes for the entire month. Moreover, low-income earners may also experience job insecurity or travel little, also contributing to the purchase of weekly fares; our results, however, are unable to address this causality. If this is indeed the case, then transit agencies, rather than providing equitable service, are placing an extra penalty on income-unstable residents by charging more per ride for weekly fares compared to monthly fares.

Our research shows that income did not influence monthly fare sales. This finding aligns with previous work in Athens, Greece that found that income had no effect on bus ridership (Gkritza et al., 2011). In addition, that vendors neighborhoods in central Montreal sell more transit fares than suburbs is expected given that metro and bus availability are confined to central 
Montreal, while suburbs are served mainly by commuter rail that require a different fare that was not included or analyzed in this study. Moreover, sales were largely dependent on whether a point of sale was a metro station; transit agencies should ensure sufficient numbers of fare vending machines are available at these types of locations.

Transit agencies increase fares to balance budgets and improve service, but this practice may place extra strain on the neediest riders (Aggarwala, 2012). Since 2013, the STM has increased monthly fares by $\$ 2.50$ a year, while weekly fares were increased by $\$ 0.75$ from 2013 to 2014 , and again by $\$ 1$ from 2014 to 2015; in comparison to monthly fares, the increase was disproportionately higher for weekly fares. To address fare equity concerns, one potential solution could be to charge the same amount per ride, so that four weekly passes cost the same total price as a 28-day fare, as in Washington, D.C. (WMATA, 2015). In London, fares are capped after a maximum specified number of trips (TfL, n.d.-a), and having caps that vary by group, like students, seniors or low-income riders, could potentially address equity concerns related to steep upfront costs. Indeed, pay as you go schemes allow riders to pay for individual rides that may be capped at the full price of a monthly fare achieving two goals related to income instability: one, riders pay low upfront costs and only for the trips they make, and two, capping fares ensures that riders are not paying a higher per-trip premium for electing to pay per trip. Another alternative is to provide a concession specifically for income-vulnerable individuals. Transit agencies in San Francisco, Seattle, and Calgary are examples of agencies that offer fare subsidizes to low-income riders (SFMTA, n.d.; C. Transit, 2015; K. C. Transit, 2015) to decrease the financial burden on socially disadvantaged populations. Using technology already in place with smartcards, the STM could enroll qualifying low-income individuals to be directly eligible for reduced fares, or alternatively, test fare capping. Interestingly, TfL offers discounts to unemployed individuals who are actively seeking employment (TfL, n.d.-b), and given that our models reveal that unemployment is predicted to increase weekly fare sales, the STM could pilot a similar type of arrangement to TfL's Job centre Plus Travel Discount Card to lower the cost of travel for job seekers.

We acknowledge the limitation of analyzing a single month's worth of purchase data. While we wished to study a larger time frame, the intensive time requirements for data extraction limited us to one month's worth of data. An important limitation of our study is that we used neighborhood-level variables as proxies for demographics of fare purchasers. Although the STM 
uses smartcards, they, similar to other agencies, do not collect personal information or link such data to smartcard usage (Pelletier, Trépanier, \& Morency, 2011; Utsunomiya, Attanucci, \& Wilson, 2006). As such, future studies should collect individual- and household-level demographics to stratify income groups and determine their impacts of fare purchases. Indeed, since our unit of analysis was individual fare vendors, our relatively small sample size makes it difficult to specify models by income strata, an important way to control for the income effect (Manaugh \& El-Geneidy, 2011). A pilot study collecting a cross-section of transit riders' social profile linked to purchase data could confirm the findings from our study, and collecting fare purchasing habits in origin-destination surveys, for instance, may increase data availability and statistical power.

Our research findings highlight the necessity of conducting fieldwork to uncover the purchasing habits of vulnerable riders. In addition to financial precarity, other vulnerable populations are also transit-dependent, such as single-parents, recent immigrants, and individuals with low educational attainment (Foth et al., 2013; Manaugh \& El-Geneidy, 2012). Initially, similar to previous equity work related to accessibility that used an index meant to capture vulnerability at the neighborhood-level (Foth et al., 2013), we also tested a combined social deprivation index and found that results were similar to the models using income and employment status. Therefore, our results indicate that other transit-dependent groups may also purchase multiple weekly fares as a substitute for a monthly fare. Nevertheless, our results are unable to reveal why low-income and unemployed individuals purchase recurrent weekly fares, though we worked with the assumption that these purchases are meant to replace monthly fares. Surveys at ticketing locations would lend credence to our assumptions and conclusions.

Moreover, future work could attempt to model single fare transactions and its potential relation with social vulnerability. Regardless, a reappraisal of transit fare structure is warranted, since raising fares for high-income riders who can afford to pay more while subsidizing low-income riders may help address not only equity concerns (Stolper \& Rankin, 2016), but also address funding shortages and improve transit quality for all (Aggarwala, 2012).

\section{ACKNOWLEDGMENTS}

We wish to thank Marc-André Gatien from the STM for the OPUS data, Rania Wasfi for advice on multilevel modeling, and Dea van Lierop for critical reading of this manuscript. Also we 
would like to thank the four anonymous reviewers for their great feedback on the earlier versions of the manuscript. Last but not least, we would like to thank Prof. Juan de Dios Ortúzar, for his feedback and support during the review process. This work was supported by a Natural Sciences and Engineering Research Council (NSERC) of Canada Discovery Grant. 


\section{References}

Aggarwala, R. T. (2012). Why Higher Fares Would Be Good for Public Transit. Retrieved from http://www.citylab.com/commute/2014/07/why-higher-fares-would-be-good-for-publictransit/374314/

APTA. (2007). A Profile of Public Transportation Passenger Demographics and Travel Characteristics Reported in On-Board Surveys. Retrieved from Washington, D.C.: http://www.apta.com/resources/statistics/Documents/transit_passenger_characteristics te xt 529 2007.pdf

Cervero, R. (1981). Flat versus differentiated transit pricing: What's a fair fare? Transportation, 10(3), 211-232.

Delbosc, A., \& Currie, G. (2011). Exploring the relative influences of transport disadvantage and social exclusion on well-being. Transport Policy, 18(4), 555-562. doi:http://dx.doi.org/10.1016/j.tranpol.2011.01.011

Delbosc, A., \& Currie, G. (2012). Choice and disadvantage in low-car ownership households. Transport Policy, 23, 8-14. doi:http://dx.doi.org/10.1016/j.tranpol.2012.06.006

Djurhuus, S., Hansen, H. S., Aadahl, M., \& Glümer, C. (2014). The association between access to public transportation and self-reported active commuting. International Journal of Environmental Research and Public Health, 11(12), 12632-12651. doi:10.3390/ijerph111212632

El-Geneidy, A., Grimsrud, M., Wasfi, R., Tétreault, P., \& Surprenant-Legault, J. (2014). New evidence on walking distances to transit stops: Identifying redundancies and gaps using variable service areas. Transportation, 41(1), 193-210.

Familar, R., Greaves, S., \& Ellison, A. (2011). Analysis of speeding behavior: Multilevel modeling approach. Transportation Research Record, 2237, 67-77. doi:doi:10.3141/2237-08

Farber, S., Bartholomew, K., Li, X., Páez, A., \& Nurul Habib, K. M. (2014). Assessing social equity in distance based transit fares using a model of travel behavior. Transportation Research Part A: Policy and Practice, 67, 291-303. doi:http://dx.doi.org/10.1016/j.tra.2014.07.013

Foth, N., Manaugh, K., \& El-Geneidy, A. (2013). Towards equitable transit: Examining transit accessibility and social need in Toronto, Canada 1996-2006. Journal of Transport Geography, 29, 1-10.

Geurs, K. T., Boon, W., \& Van Wee, B. (2009). Social impacts of transport: Literature review and the state of the practice of transport appraisal in the Netherlands and the United Kingdom. Transport Reviews, 29(1), 69-90. doi:10.1080/01441640802130490

Giuliano, G. (2005). Low income, public transit, and mobility. Transportation Research Record, 1927, 63-70.

Gkritza, K., Karlaftis, M. G., \& Mannering, F. L. (2011). Estimating multimodal transit ridership with a varying fare structure. Transportation Research Part A: Policy and Practice, 45(2), 148-160. doi:http://dx.doi.org/10.1016/j.tra.2010.12.005

Glaeser, E. L., Kahn, M. E., \& Rappaport, J. (2008). Why do the poor live in cities? The role of public transportation. Journal of Urban Economics, 63(1), 1-24. doi:http://dx.doi.org/10.1016/j.jue.2006.12.004 
Hickey, R. L. (2005). Impact of transit fare increase on ridership and revenue: Metropolitan Transportation Authority, New York City. Transportation Research Record, 1927, 239248. doi:doi:10.3141/1927-27

Hickey, R. L., Lu, A., \& Reddy, A. (2010). Using quantitative methods in equity and demographic analysis to inform transit fare restructuring decisions. Transportation Research Record(2144), 80-92.

Krumholz, N., \& Forester, J. (1990). Making Equity Planning Work: Leadership in the Public Sector. Philadelphia: Temple University Press.

Manaugh, K., Badami, M. G., \& El-Geneidy, A. (2015). Integrating social equity into urban transportation planning: A critical evaluation of equity objectives and measures in transportation plans in North America. Transport Policy, 37, 167-176. doi:http://dx.doi.org/10.1016/j.tranpol.2014.09.013

Manaugh, K., \& El-Geneidy, A. (2011). Validating walkability indices: How do different households respond to the walkability of their neighbourhood? Transportation Research Part D: Transport and Environment, 16(4), 309-315.

Manaugh, K., \& El-Geneidy, A. (2012). Who benefits from new transportation infrastructure? Using accessibility measures to evaluate social equity in public transport provision. In K. Geurs, K. Krizek, \& A. Reggiani (Eds.), Accessibility and Transport Planning: Challenges for Europe and North America (pp. 211-227). London, UK: Edward Elgar.

Martens, K. (2012). Justice in transport as justice in accessibility: applying Walzer's 'Spheres of Justice' to the transport sector. Transportation, 39(6), 1035-1053. doi:10.1007/s11116012-9388-7

Martens, K. (2017). Transport justice: Desiging fair transportation systems. New York: Routledge.

Nuworsoo, C., Golub, A., \& Deakin, E. (2009). Analyzing equity impacts of transit fare changes: Case study of Alameda-Contra Costa Transit, California. Evaluation and Program Planning, 32(4), 360-368. doi:http://dx.doi.org/10.1016/j.evalprogplan.2009.06.009

Pelletier, M.-P., Trépanier, M., \& Morency, C. (2011). Smart card data use in public transit: A literature review. Transportation Research Part C: Emerging Technologies, 19(4), 557568. doi:http://dx.doi.org/10.1016/j.trc.2010.12.003

Ross, N. A., Tremblay, S., \& Graham, K. (2004). Neighbourhood influences on health in Montréal, Canada. Social Science \& Medicine, 59(7), 1485-1494. doi:http://dx.doi.org/10.1016/j.socscimed.2004.01.016

Schuerman, M. (2015). Why MetroCards Are Like Paper Towels. Retrieved from http://www.wnyc.org/story/why-metrocards-are-paper-towels/

SFMTA. (n.d.). Muni Lifeline Screening Tool. Retrieved from http://www.munilifeline.org/index.cfm

STM. (2015). OPUS Card. Retrieved from http://www.stm.info/en/info/fares/opus-cards-andother-fare-media/opus-card

Stolper, H., \& Rankin, N. (2016). The Transit Affordability Crisis: How Reduced MTA Fares Can Help Low-Income New Yorkers Move Ahead. Retrieved from New York:

Taylor, B., \& Morris, E. (2015). Public transportation objectives and rider demographics: are transit's priorities poor public policy? Transportation, 42(2), 347-367. doi:10.1007/s11116-014-9547-0

Taylor, B. D., \& Norton, A. T. (2009). Paying for transportation: What's a fair price? Journal of Planning Literature, 24(1), 22-36. 
TfL. (n.d.-a). Capping-Transport for London. Retrieved from https://tfl.gov.uk/fares-andpayments/oyster/using-oyster/price-capping

TfL. (n.d.-b). Jobcentre Plus Travel Discount-Transport for London. Retrieved from https://tfl.gov.uk/fares-and-payments/adult-discounts-and-concessions/jobcentre-plustravel-discount?intcmp $=1754$

Transit, C. (2015). Low Income Monthly Pass. Retrieved from http://www.calgarytransit.com/fares-passes/passes/low-income-monthly-pass

Transit, K. C. (2015). ORCA LIFT Reduced Fare Program - King County Metro Transit. Retrieved from http://metro.kingcounty.gov/programs-projects/orca-lift/

Utsunomiya, M., Attanucci, J., \& Wilson, N. (2006). Potential uses of transit smart card registration and transaction data to improve transit planning. Transportation Research Record, 1971, 119-126.

Wang, Z. J., Li, X. H., \& Chen, F. (2015). Impact evaluation of a mass transit fare change on demand and revenue utilizing smart card data. Transportation Research Part A: Policy and Practice, 77, 213-224. doi:http://dx.doi.org/10.1016/j.tra.2015.04.018

Wasfi, R. A., Ross, N. A., \& El-Geneidy, A. M. (2013). Achieving recommended daily physical activity levels through commuting by public transportation: Unpacking individual and contextual influences. Health \& Place, 23, 18-25. doi:http://dx.doi.org/10.1016/j.healthplace.2013.04.006

Welch, T. F. (2013). Equity in transport: The distribution of transit access and connectivity among affordable housing units. Transport Policy, 30, 283-293. doi:http://dx.doi.org/10.1016/j.tranpol.2013.09.020

WMATA. (2015). Metro - Fares. Retrieved from http://www.wmata.com/fares/purchase/passes.cfm 